\title{
Effectiveness of Education Security Managers in Leadership Competence at WSB University (in Poznan and in Gdansk) and at University of Defence in Brno, on the Undergraduate Internal Security Studies
}

\author{
Edyta Ślachcińska \\ Faculty of Finance and Banking \\ WSB University in Poznan \\ Poznan, Poland \\ e-mail: edyta.slachcinska@wsb.poznan.pl
}

\author{
Ilona Ziemkiewicz-Gawlik \\ Faculty of Finance and Banking \\ WSB University in Poznan \\ Poznan, Poland \\ e-mail: ilona.ziemkiewicz-gawlik@wsb.poznan.pl
}

\author{
Radomir Saliger \\ University of Defence in Brno \\ Brno, Czech Republic \\ e-mail: radomir.saliger@unob.cz
}

\begin{abstract}
The article refers to examinations conducted at Higher Bank School in Poznan and in Gdansk and at University of Defence in Brno, on the field of internal security undergraduate studies, by which students of the 6. semesters were encompassed. Aim of examination was establishing, whether Colleges fulfil a duty of educating managers of Security studies across the leadership competence range.
\end{abstract}

Keywords-manager of the security; leadership competence; training leadership competence

\section{INTRODUCTION}

In relation to dynamic social transformations in the world, dynamics of changes of civilization and threats accompanying these processes, security education is a matter of particular importance [1]. The folded political situation in contemporary world causes the need for creating and developing courses in higher education institutions which would be able to answer to the demand and practical preparing the staff in the field of security and the public order, including the managing staff.

Managing the state security, is basically assuming by competent authorities (security managers of individual levels of the management), under the entrusted competence, such decisions that in effect will keep the desired security level of security in every field of activity of the state, but also taking appropriate action, when risks are present. [2]. The security managers stand at the forefront of teams and are responsible for the implementation of operations of people reporting to them, therefore, attention should be paid at training of security manager in the field of leadership competence.

\section{TRAINING ON LEADERSHIP COMPETENCE}

According to W. Okoń, education is the overall action (external and internal) that enabling people to get to know the nature, societies and cultures, and the participation in their shaping, and at the same time achieving the highest possible level of the comprehensive development, ability and talents, interests and avocations, beliefs and attitudes, as well as acquiring desired professional qualifications [3]. The education is action proceeding into the regular basis, that is repeating itself, so it can be said about the process of educating.

The process of educating may be considered in the aspect of the sequence of intentional changes, occurring in the trainee person, taught by the teacher, in the form of achieving established purposes which educations are a result of the set of diversified activities. Among them, the most often appointed by the program are acquiring and developing by the educated person:

- messages,

- ability,

- habits,

- determined views, beliefs and attitudes,

- interests,

- $\quad$ cognitive abilities, self-learning attitudes.

The education process is a basic element of the academic work. At the beginning of this process there are a level of the knowledge, the ability and attitudes of students who begin their training and their activity in the process of educating. On the way in there are: the knowledge, abilities and attitudes the student is purchasing which during the process.

The process of educating should be led to be effective. It is possible to describe the effectiveness education by comparing the results with adopted aims of the education [4].

K. Żegnałek thinks that to the effectiveness of the process of education and the quality of graduates, are affecting for example on: the quality of candidates for students, the program of education, the quality of university teachers and motivation of students [5].

In the process of educating of security managers in the leadership competence range, at the beginning, the 
following question should be answered: How to educate students with leadership competences?

The education that veer away from established aims, without an appropriate educational program, conducted unsystematically and by unsuitable people which don't have suitable qualifications in this respect, will not allow to acquire leadership competence by students. In the process of educating the security managers in leadership competence, one should take into account, that the leadership is an interdisciplinary and multifaceted notion. Interdisciplinary character of the leadership means that he regards such fields and disciplines as:

- social science, in the field of the social science includes the following disciplines: theories about the cognition and the social communication, theories about politics, theories about public politics, pedagogy, psychology, sociology;

- social science, in the field of economic studies includes the following disciplines: management studies;

- humanities, including the following disciplines: philosophy, linguistics, cultural studies, management studies.

According to J. Borkowski, educating students in leadership competence, above all, should include the following elements [6]:

- knowledge about the notion and basis of the leadership, methods of educating about it and about results of its lack;

- thinking focused on the partnership, not on the things, objects, means, but aimed at leadership cooperating with subordinates;

- confidence in relations between subordinates and superiors;

- professional and moral authority.

\section{Characteristics OF AREA AND THE RESEARCH ATTEMPT}

As a part of research there was a diagnostic survey was conducted amongst the students of 6 . semester of undergraduate studies, studying on the field of internal security at Higher Bank School in Poznan and in Gdansk and at University of Defence in Brno.

The aim of research was an identification of the students leadership competence and factors which have a positive impact on the educational process. A research tool was a questionnaire.

The research was conducted amongst 246 students (61 students in Poznan, 107 students in Gdansk and 78 in Brno), on full-time studies - 137 persons and extramular - 109 persons. Students in Poznan are studying the public safety and the crisis management, students in Gdansk - secret service and police, while students in Brno - civil protection, cyber security and security services.

Students took part in the questionnaire survey both of sex. Women formed the majority amongst the respondents the $50.81 \%$, while men accounted $49.19 \%$ of respondents.
Respondents at the age of 25 ( $82.11 \%$ of respondents) presented the majority, next at the age of $26-35$ (13.41\% of respondents) and above 35 years old (4.47\% of respondents).

Amongst respondents the $50.81 \%$ do not have a job, while the $49.19 \%$ are employed. In the group of employees the $57.02 \%$ performs work connected with their field of studies, whereas $42.98 \%$ of them do the job without security involved in it.

\section{SELF-ASSESSMENT OF COMPETENCE OF LEADERSHIP} MANAGERS OF THE SAFETY AT THE WSB UNIVERSITY IN POZNŃ AND IN GDAŃSK AND AT UNIVERSITY OF DEFENCE IN BRNO

On the basis of an analysis of literature leadership competence that security managers should possess were distinguished:

- composed (calm) in difficult situations,

- energetic in action, likes challenges,

- self-confident, bold in expressing own opinions,

- consistent and persistent,

- easiness of winning the confidence, of winning other,

- feeling empathy (understanding emotions and the situation of other person),

- urgent, punctual, well-organized,

- makes decisions easily and quickly,

- takes responsibility for its,

- abilities of motivating others into action,

- abilities to cooperate in the group,

- groups management skills,

- capacity to work under pressure of time,

- is able to convince others to its ideas,

- takes a responsibility for its and the others actions,

- acts in line with promises, is reliable.

In order to identify the level of students individual leadership competence, they had been asked to refer to the written statements in scale from 1 to 3 (1 - no, 2 - neither yes nor no, 3 - yes). The results were presented in the tables below.

TABLE I. I AM ABLE TO OVERCOME DifFICULT SitUATIONS

\begin{tabular}{|c|c|c|c|c|}
\hline Answers & Poznań & Gdańsk & Brno & Together \\
\hline No & 12 & 16 & 2 & 30 \\
\hline $\begin{array}{c}\text { Neither yes } \\
\text { nor no }\end{array}$ & 18 & 20 & 16 & 54 \\
\hline Yes & 31 & 71 & 60 & 162 \\
\hline
\end{tabular}

TABEL II. I AM ENERGETIC IN ACTION, I LIKE CHALLENGES

\begin{tabular}{|c|c|c|c|c|}
\hline Answers & Poznań & Gdańsk & Brno & Together \\
\hline No & 3 & 5 & 3 & 11 \\
\hline $\begin{array}{c}\text { Neither yes } \\
\text { nor no }\end{array}$ & 15 & 24 & 15 & 54 \\
\hline Yes & 43 & 78 & 60 & 181 \\
\hline
\end{tabular}


TABEL III. I AM SELF-CONFIDENT, I DARE TO EXPRESS MY OWN OPINION

\begin{tabular}{|c|c|c|c|c|}
\hline Answers & Poznań & Gdańsk & Brno & Together \\
\hline No & 11 & 11 & 9 & 31 \\
\hline $\begin{array}{c}\text { Neither yes } \\
\text { nor no }\end{array}$ & 19 & 27 & 13 & 59 \\
\hline Yes & 31 & 69 & 56 & 156 \\
\hline
\end{tabular}

TABEL IV. I AM CONSISTENT AND PERSISTENT IN PURSUING MY AIMS

\begin{tabular}{|c|c|c|c|c|}
\hline Answers & Poznań & Gdańsk & Brno & Together \\
\hline No & 0 & 3 & 6 & 9 \\
\hline $\begin{array}{c}\text { Neither yes } \\
\text { nor no }\end{array}$ & 9 & 30 & 10 & 49 \\
\hline Yes & 52 & 74 & 62 & 188 \\
\hline
\end{tabular}

TABEL V. I HAVE GOT A SOCIAL EASE OF BUILDING THE TRUST, WINNING OVER THE OTHERS

\begin{tabular}{|c|c|c|c|c|}
\hline Answers & Poznań & Gdańsk & Brno & Together \\
\hline No & 4 & 5 & 5 & 14 \\
\hline $\begin{array}{c}\text { Neither yes } \\
\text { nor no }\end{array}$ & 15 & 20 & 16 & 51 \\
\hline Yes & 42 & 82 & 57 & 181 \\
\hline
\end{tabular}

TABEL VI. ICAN FEEL EMPATHY (OF UNDERSTANDING EMOTIONS AND THE SITUATION OF OTHER PERSON)

\begin{tabular}{|c|c|c|c|c|}
\hline Answers & Poznań & Gdańsk & Brno & Together \\
\hline No & 2 & 9 & 6 & 17 \\
\hline $\begin{array}{c}\text { Neither yes } \\
\text { nor no }\end{array}$ & 19 & 19 & 10 & 48 \\
\hline Yes & 40 & 79 & 62 & 181 \\
\hline
\end{tabular}

TABEL VII. I AM DILIGENT, PUNCTUAL AND WELL-ORGANIZED

\begin{tabular}{|c|c|c|c|c|}
\hline Answers & Poznań & Gdańsk & Brno & Together \\
\hline No & 4 & 9 & 9 & 22 \\
\hline $\begin{array}{c}\text { Neither yes } \\
\text { nor no }\end{array}$ & 13 & 20 & 22 & 55 \\
\hline Yes & 44 & 78 & 47 & 169 \\
\hline
\end{tabular}

TABEL VIII. I MAKE MY DECISIONS EASILY AND QUICKLY

\begin{tabular}{|c|c|c|c|c|}
\hline Answers & Poznań & Gdańsk & Brno & Together \\
\hline No & 10 & 10 & 18 & 38 \\
\hline $\begin{array}{c}\text { Neither yes } \\
\text { nor no }\end{array}$ & 20 & 31 & 22 & 73 \\
\hline Yes & 31 & 66 & 38 & 135 \\
\hline
\end{tabular}

TABEL IX. ITAKE THE RESPONSIBILITY FOR MY ACTION

\begin{tabular}{|c|c|c|c|c|}
\hline Answers & Poznań & Gdańsk & Brno & Together \\
\hline No & 0 & 1 & 2 & 3 \\
\hline $\begin{array}{c}\text { Neither yes } \\
\text { nor no }\end{array}$ & 7 & 13 & 3 & 23 \\
\hline Yes & 54 & 93 & 73 & 220 \\
\hline
\end{tabular}

TABEL X. I HAVE SKILLS OF MOTIVATING OTHERS INTO ACTION

\begin{tabular}{|c|c|c|c|c|}
\hline Answers & Poznań & Gdańsk & Brno & Together \\
\hline No & 5 & 8 & 8 & 21 \\
\hline $\begin{array}{c}\text { Neither yes } \\
\text { nor no }\end{array}$ & 20 & 27 & 21 & 68 \\
\hline Yes & 36 & 72 & 49 & 157 \\
\hline
\end{tabular}

TABEL XI. I HAVE TEAMWORK SKILLS

\begin{tabular}{|c|c|c|c|c|}
\hline Answers & Poznań & Gdańsk & Brno & Together \\
\hline No & 4 & 5 & 9 & 18 \\
\hline $\begin{array}{c}\text { Neither yes } \\
\text { nor no }\end{array}$ & 11 & 17 & 7 & 35 \\
\hline Yes & 46 & 85 & 62 & 193 \\
\hline
\end{tabular}

TABEL XII. I Have Group MANAGEMENT SKILLS

\begin{tabular}{|c|c|c|c|c|}
\hline Answers & Poznań & Gdańsk & Brno & Together \\
\hline No & 10 & 13 & 6 & 29 \\
\hline $\begin{array}{c}\text { Neither yes } \\
\text { nor no }\end{array}$ & 19 & 28 & 27 & 74 \\
\hline Yes & 32 & 66 & 45 & 143 \\
\hline
\end{tabular}

TABEL XIII. I AM ABLE TO WORK UNDER PRESSURE OF TIME

\begin{tabular}{|c|c|c|c|c|}
\hline Answers & Poznań & Gdańsk & Brno & Together \\
\hline No & 4 & 5 & 3 & 12 \\
\hline $\begin{array}{c}\text { Neither yes } \\
\text { nor no }\end{array}$ & 10 & 27 & 7 & 44 \\
\hline Yes & 47 & 75 & 68 & 190 \\
\hline
\end{tabular}

TABEL XIV. I AM ABLE TO CONVINCE OTHER TO MY IDEAS

\begin{tabular}{|c|c|c|c|c|}
\hline Answers & Poznań & Gdańsk & Brno & Together \\
\hline No & 3 & 1 & 6 & 10 \\
\hline $\begin{array}{c}\text { Neither yes } \\
\text { nor no }\end{array}$ & 13 & 28 & 21 & 62 \\
\hline Yes & 45 & 78 & 51 & 174 \\
\hline
\end{tabular}

TABEL XV. IT AKE THE RESPONSIBILITY FOR MY AND THE OTHERS ACTION

\begin{tabular}{|c|c|c|c|c|}
\hline Answers & Poznań & Gdańsk & Brno & Together \\
\hline No & 5 & 5 & 3 & 13 \\
\hline $\begin{array}{c}\text { Neither yes } \\
\text { nor no }\end{array}$ & 22 & 23 & 11 & 56 \\
\hline Yes & 34 & 79 & 64 & 177 \\
\hline
\end{tabular}

TABEL XVI. I ACT IN LINE WITH MY PROMISES, I AM RELIABLE

\begin{tabular}{|c|c|c|c|c|}
\hline Answers & Poznań & Gdańsk & Brno & Together \\
\hline No & 1 & 0 & 4 & 5 \\
\hline $\begin{array}{c}\text { Neither yes } \\
\text { nor no }\end{array}$ & 8 & 16 & 7 & 31 \\
\hline Yes & 52 & 91 & 67 & 210 \\
\hline
\end{tabular}


From among list of leadership competence, the most surveyed people chose the responsibility for its action (220 persons granted the positive answer). The responsibility for its action manifests itself above all in taking the consequences of its act and decision, but also in fulfilling promises, discharging of duties and predicting the results of taken action.

Responsible persons are able to admit when they are wrong and are bear responsibility for consequences of their actions. A sense of responsibility is one of basic competence of the leadership. Those who are responsible for its acts are considered by other people seriously, generate respect and cause, that other people are willing to are cooperate with them.

As the second from the set of leadership competence, students chose acting in accordance with promises, being a man of his word (210 students gave affirmative answer).

Possessing the teamwork skill is third most often selected leadership competence (193 persons respond in this way).

However to the lowest-rated competence fall within: I make my decisions easily and quickly (38 persons showed that they do not have this competence) as well as I am selfconfident, I dare to express own opinions (31 persons showed that they do not have this competence). It means that colleges should focus greater attention on educating students in this respect.

\section{EFFECTIVENESS IN THE PROCESS OF EDUCATING} STUDENTS IN LEADERSHIP COMPETENCE IN THE VIEW OF THE STUDENTS OF WSB UNIVERSITY IN POZNAŃ AND GDAŃSK AND

\section{STUDENTS OF UNIVERSITY OF DEFENCE IN BRNO}

Intending to cognition, what the effectiveness in the process of educating in leadership competence is, students of WSB University in Poznan and in Gdansk and at University of Defence in Brno were asked a number of questions, which results were presented in tables below.

TABEL XVII. OPINIONS OF RESPONDENTS CONCERNING THE SUFFICIENT NuMBER OF SUBJECTS CONTAINING THE EDUCATIONAL CONTENT FROM THE SCOPE OF LEADERSHIP

\begin{tabular}{|c|c|c|c|c|}
\hline Answers & Poznań & Gdańsk & Brno & Together \\
\hline No & 10 & 37 & 25 & 72 \\
\hline $\begin{array}{c}\text { Neither yes } \\
\text { nor no }\end{array}$ & 24 & 27 & 19 & 70 \\
\hline Yes & 27 & 43 & 34 & 104 \\
\hline
\end{tabular}

TABEL XVIII. OPINIONS OF RESPONDENTS CONCERNING THE SUFFICIENT NUMBER OF HOURS OF EXECUTION THE EDUCATIONAL CONTENT FROM THE SCOPE OF LEADERSHIP

\begin{tabular}{|c|c|c|c|c|}
\hline Answers & Poznań & Gdańsk & Brno & Together \\
\hline No & 12 & 36 & 28 & 76 \\
\hline $\begin{array}{c}\text { Neither yes } \\
\text { nor no }\end{array}$ & 26 & 30 & 16 & 72 \\
\hline Yes & 23 & 41 & 34 & 98 \\
\hline
\end{tabular}

The data described in tables XVII and XVIII shows that surveyed students think that in current educational programmes there is an adequate number of subjects containing the education contents from the scope of leadership and sufficient number of hours of the realization the contents of education from the scope of leaderships.

Respondents were also asked, whether during studies, an appropriate sequence of the subjects concerning the leadership was implemented, which means the arrangement of the subject in the correct order which let the education contents executed within frames of each subject, to be the background to launch studying of another one. Small majority of students (90 persons) thinks that the subjects concerning the leadership had not been carried out in the right sequence. The results were presented in the XIX table.

TABEL XIX. OPINIONS OF RESPONDENTS CONCERNING THE APPROPRIATE SEQUENCE OF SUBJECTS CONT AINING THE EDUCATION CONTENTS FROM THE SCOPE OF LEADERSHIP

\begin{tabular}{|c|c|c|c|c|}
\hline Answers & Poznań & Gdańsk & Brno & Together \\
\hline No & 17 & 37 & 36 & 90 \\
\hline $\begin{array}{c}\text { Neither yes } \\
\text { nor no }\end{array}$ & 21 & 28 & 23 & 72 \\
\hline Yes & 23 & 42 & 19 & 84 \\
\hline
\end{tabular}

It should be mentioned that a teaching staff is responsible for the due completion of the process of educating. Teacher is a person who should be aware that an effectiveness of the process of educating depends on it. the Academic teachers are expected to be able to use the expertise, be prepared for giving classes, as well as, is ready to cooperate with others, indicating responsibility and following ethical principles.

In order to assess whether academic teachers conducting classes at the WSB University in Poznan, Gdansk and at the University of Defence in Brno with leadership subjects are competent in carrying out their duties, respondents were asked to express their views on the subject. The results are presented below.

TABEL XX. STUDENT'S EVALUATION OF COMPETENCES OF LECTURERS TEACHING SUBJECTS CONNECTED WITH LEADERSHIP AS REGARDS ITS EXISTING KNOWLEDGE OF CONDUCTING CLASSES

\begin{tabular}{|c|c|c|c|c|}
\hline Answers & Poznań & Gdańsk & Brno & Together \\
\hline No & 6 & 5 & 13 & 24 \\
\hline $\begin{array}{c}\text { Neither yes } \\
\text { nor no }\end{array}$ & 22 & 17 & 13 & 52 \\
\hline Yes & 33 & 85 & 52 & 170 \\
\hline
\end{tabular}

TABEL XXI. STUDENT'S EVALUATION OF COMPETENCES OF LECTURERS TEACHING SUBJECTS CONNECTED WITH LEADERSHIP AS REGARDS ITS ABILITY OF TRANSFERING THE KNOWLEDGE

\begin{tabular}{|c|c|c|c|c|}
\hline Answers & Poznań & Gdańsk & Brno & Together \\
\hline No & 5 & 3 & 11 & 19 \\
\hline $\begin{array}{c}\text { Neither yes } \\
\text { nor no }\end{array}$ & 14 & 15 & 15 & 44 \\
\hline Yes & 42 & 89 & 52 & 183 \\
\hline
\end{tabular}


The results of the study indicate that didactic staff conducting classes with leadership subjects at the WSB University in Poznan and in Gdansk and at the University of Defence in Brno are competent. Students highly valued both their knowledge of conducting classes (170 answers Yes), and ability to pass it to their students (183 replies Yes).

\section{CONCLUSION}

The conducted survey shows that the current process of education of safety managers in the leadership at the WSB University in Poznan and in Gdansk and at the University of Brno ensures that the students acquire leadership competences and thus is effective.

Students considered that the current learning programme contain a sufficient number of subjects with leadership education content and a sufficient number of hours of leadership training content. There just should be paid more attention to the proper order of execution of these items.

Respondents also agreed that lecturers teaching the leadership subjects have knowledge in this field, as well as have the necessary skills to take advantage of these in the classroom.

\section{REFERENCES}

[1] P. Sztompka, Socjologia zmian społecznych, Kraków 2012, p. 356389.

[2] W. Molek, K. Stec, R. Marciniak, Zarządzanie kryzysowe w systemie kierowania bezpieczeństwem narodowym [in:] Bezpieczeństwo Narodowe, Vol. 17 (2005), p. 47.

[3] W. Okoń, Wprowadzenie do dydaktyki ogólnej, Warszawa 1995, p. 41.

[4] S. Palka, Skuteczność procesu kształcenia studentów uniwersyteckiego kierunku nauczanie początkowe [in:] Skuteczność kształcenia nauczycieli klas początkowych, ed. H. Moroz, Katowice 1993, p. 22.

[5] K. Żegnałek, Jakość czy bylejakość edukacji nauczycielskiej [in:] Jakość wobec wyzwań i zagrożeń XXI wieku, E. Slachcińska, A. Zduniak (red. nauk.) Edukacja XXI w. (t. 3/24), Poznań 2011, s. 117; T. Wawak, S. Wawak, Polemiczny głos w sprawie jakości kształcenia w Polsce na przykładzie nauk ekonomicznych, „Problemy Jakości” Vol. 10 (2001), p. 26.

[6] J. Borkowski, Zasady kształtowania kompetencji interpersonalnych dowódców [in:] Vedemecum dydaktyczno-wychowawcze, Warszawa 1997, p. 284. 